\title{
Pyoderma Profile In The Dermato-Venereology Outpatient Unit Of Aisyiyah Islamic Hospital Malang On January-December 2017
}

\author{
Sri Adila Nurainiwati ${ }^{1}$, Mira Wiji Lestari ${ }^{2}$ \\ ${ }^{1}$ Department of Dermatology and Venereology, University of Muhammadiyah Malang \\ ${ }^{2}$ Medical Faculty Students, University of Muhammadiyah Malang \\ Email : ninin_eb@yahoo.co.id \\ Receive : March $28^{\text {th }}$ 2020. Revised : May $25^{\text {th }}$ 2020. Published: Jun $27^{\text {th }} 2020$
}

DOI: https://doi.org/10.22219/sm.Vol16.SMUMM1.12734

\begin{abstract}
Background:Pyoderma is a skin infection caused by gram-positive bacteria such as Staphylococcus, Streptococcus, or both, which are still one of the main problems causing high morbidity rates, especially in developing countries and tropical climates, including Indonesia.

Objective: To find out the pattern of pyoderma in the outpatients from Dermatovenereology unit of AisyiyahIslamic Hispital on January-December 2017.

Methods: This retrospective study extracted data from the medical records of Dermatovenereology outpatient unit of AisyiyahIslamic Hospital in the January-December 2017 time frame.

Results: The incidence of pyoderma at Aisyiyah Islamic Hospital in Malang during 2017 was 46 cases $(11.03 \%)$. The incidence of pyoderma is higher in males (56.52\%) and according to age, the most affected age group is $0-11$ years $(39 \%)$. The most common level of education is SMA/MA (high school), which is $34.78 \%$. Most types of pyoderma are impetigo (32.6\%). The most used systemic antibiotic therapy is cefixime at $35.71 \%$ and the most used topical therapy is mupirocin (42.86\%).

Conclusion: The most impetigo type of pyoderma, males, with the most age group is 0-11 years, high school education level, the most used systemic therapy is cefixime and the most used topical therapy is mupirocin.
\end{abstract}

Keyword: pyoderma, aisyiyahislamic hospital

Copyright (C) 2020, First Author et al

This is an open access article under the CC-BY-SA license

\section{INTRODUCTION}

Pyoderma is a bacterial skin infection, mainly caused by Staphylococcus aureus and Streptococcus sp. Predisposing or contributing factors to the occurrence of pyoderma include atopic dermatitis, immunosuppression, pre-existing tissue injury, inflammation, and systemic diseases such as diabetes mellitus. Various other factors such as malnutrition, population density, poor hygiene, and low socio-economic factors could also lead to pyoderma. (Craft et al, 2008)

Pyoderma has various forms of clinical manifestations. Pyoderma is generally divided into primary pyoderma and secondary pyoderma. Primary pyoderma are impetigo, folliculitis, furuncle, 
carbuncle, ecthyma, and erythrasma. Whereas secondary pyoderma includes tropic ulcers, infected pemphigus, infected contact dermatitis, infected scabies, and various other dermatoses infected by organism. (Gandhi S, Ojha Ak, Ranjan KP et al, 2012)

Pyoderma is one of the most common clinical conditions found in dermatological practice. (Gandhi S, Ojha Ak, Ranjan KP et al, 2012) In the Department of Dermatovenereology, Medical Faculty, University of Indonesia, pyoderma incident was ranked third. (Djuanda A, Hamzah M, Aisah S, 2011) The prevalence of pyoderma in several countries such as in Brazil, Ethiopia, Taiwan and others is $0.2-35 \%$, while the prevalence in Indonesia is $1.4 \%$ in adults and $0.2 \%$ in children. (WHO, 2005)

Based on the description above, the research will be conducted on the profile of patients with pyoderma which includes age, sex, socio-economic and educational factors, as well as the treatment and clinical forms of pyoderma in the Islamic Hospital of Aisyiah Malang period January - December 2017.

\section{METHODS}

This type of research is a descriptive retrospective based on medical records from the period January 1st to December 31th, 2017 from the Islamic Hospital of Aisyiah Malang. The study was in the form of secondary data from a patient registration book regarding pyoderma prevalence. Data was displayed in tabular and diagram form including the number of patients, sex, patient age, occupation, symptoms, diagnosis, and therapy. The population was all medical records of dermatovenereology polyclinic patients in Malang Aisyiyah Hospital in the period January 1st December 31th. The sample was all medical records of Dermatovenereology polyclinic patients in Malang Aisyiyah Hospital in the period January 1st - December 31th, 2017 with a diagnosis of pyoderma. The sampling technique in this study used the total sample method.

\section{RESULTS AND DISCUSSION}

Based on the results of the study conducted at Dermatovenereology Outpatient Unit of Aisyiyah Islamic Hospital Malang in the period of January 1st to December 31th, 2017, the total number of patients with pyoderma was 46 cases $(11.03 \%)$.

\section{Age Distribution of Pyoderma Patients}

Based on medical record data obtained from the outpatient unit of the Islamic Hospital of Aisyiyah Malang, the age distribution of pyoderma patients is as follows: 
Table 1. Age Distribution of Pyoderma Patients

\begin{tabular}{ccc}
\hline Age Range (years old) & Number of Patients & Percentage (\%) \\
\hline $0-11$ & 18 & 39 \\
$12-25$ & 13 & 28 \\
$26-45$ & 9 & 20 \\
$46-65$ & 6 & 13 \\
\hline Total & 46 & 100 \\
\hline
\end{tabular}

The biggest age group is 0 - 11 years old with 18 cases (39\%), while the smallest age group of 46 - 65 years old is 6 cases $(13 \%)$. The results of this study are the same as the results of research conducted at Sanglah Hospital Denpasar in the period January - December 2015, which is $51.7 \%$ in the age group 0-11 years old. (Listya P, et. al., 2015) Likewise, research conducted at General Hospital Dr. Soetomo Surabaya in the period 2008-2010 also found that the most age is 1-4 years old. (LaksmiDewi BAAA. et. al., 2006) Preschool and school age children also have predisposing factors that make it easier for them to acquire pyoderma. There are differences in the skin's defense system in infants and children differently than adults such as the thickness of the epidermis, dermis, sweat gland function and sebum. This facilitates the process of infection of the skin. During childhood, children also begin to recognize the environment and explore the natural surroundings, making it easier for the entry of pathogenic bacteria plus hygiene and sanitation which is less contributing to worsening the skin condition in children. (Craft et. al., 2008. John, H. 2013)

\section{Sex Distribution of Pyoderma Patients}

Based on medical record data obtained from the outpatient unit of the Islamic Hospital of Aisyiyah Malang, it is found that the sex distribution of patients with pyoderma is as follows:

Table 2. Sex Distribution of Pyoderma Patients

\begin{tabular}{ccc}
\hline Sex & Number of patients & Percentage (\%) \\
\hline Male & 26 & 56,52 \\
Female & 20 & 43,48 \\
\hline Total & 46 & 100 \\
\hline
\end{tabular}

The table above shows that the percentage of pyoderma incidence in Malang Aisyiyah Hospital was higher in males as many as 26 cases (56.52\%) than males as many as 20 cases $(43.48 \%)$. The same results come from a study conducted at Sanglah Hospital in Denpasar in 2015, 
which stated that pyoderma was higher in males as many as 33 cases $(58.9 \%)$ compared to males as much as 23 cases (41.07\%). Nugraha, 2017 stated in his research that there was no relationship between sex and bacterial infection of the skin. (Nugraha, Dhimas P, 2017)

\section{Distribution of Education Level of Pyoderma Patients}

In accordance with the data in the medical records obtained from the outpatient unit of the Islamic Hospital of Aisyiyah Malang, the distribution of pyoderma patient education is as follows:

Table 3. Education Level Distribution of Pyoderma Patients

\begin{tabular}{ccc}
\hline Education Level & Number of Patients & Percentage (\%) \\
\hline Preschool & 6 & 13,04 \\
Elementary School & 12 & 26,09 \\
Junior High School & 4 & 8,70 \\
High School & 16 & 34,78 \\
Bachelor & 8 & 17,39 \\
\hline Total & 46 & 100 \\
\hline
\end{tabular}

The data above shows the most pyoderma patients are in high school education level that is $34.78 \%$. A higher level of education is often associated with an individual's level of knowledge. The higher person's education, the more information he gets so the higher his knowledge. Education is also one of the factors that influence one's perception. Because it can make someone easier to make decisions and act. This includes knowledge about good personal hygiene that can improve individual health. (Notoatmodjo, S, 2002) Therefore, it should be, the higher a person's education, the lower the prevalence of pyoderma. Low education can contribute to low socioeconomic conditions. Low socioeconomic can cause low nutrient intake so it can decrease the immune system. Low immune bodies have a higher risk of skin infections. (Depari LI, Sugiri U, Ilona L, 2016) But based on the data above, high school education level has a high percentage. This is because in addition to hygiene factors, many other factors can cause pyoderma.

\section{Distribution of Pyoderma Types}

Based on medical record data obtained from the outpatient unit of the Islamic Hospital of Aisyiyah Malang, the distribution of pyoderma types is as follows: 
Table 4. Distribution of Pyoderma Types

\begin{tabular}{ccc}
\hline Pyoderma Types & Number of Patients & Percentage (\%) \\
\hline Impetigo & 15 & 32,6 \\
Ecthyma & 10 & 21,7 \\
Folliculitis & 7 & 15,3 \\
Furuncle & 9 & 19,5 \\
Erysipelas & 2 & 4,4 \\
Cellulitis & 3 & 6,5 \\
\hline Total & 46 & 100 \\
\hline
\end{tabular}

The results showed that the most pyoderma type was impetigo, 15 cases $(32.6 \%)$, followed by 10 cases $(21.7 \%)$ and at least eripselas 2 cases (4.4\%). Research in other hospitals also found that impetigo was the most common, in Surabaya Soetomo Hospital, impetigo was found to be $40.5 \%$. (Caren CP, 2012) Research conducted at the Dermatovenereology Polyclinic Prof. Dr. R. D. Kandou Manado in the period of 2013-2015 showed the same results where the most common pyoderm type is impetigo. (Priscilia F. Lumataw, PandalekeH, Pieter LS., 2013) Another study conducted by the Department of Microbiology, Gajra Raja Medical College, India by Gandhi revealed the same thing where impetigo is the most common pyoderma types, followed by folliculitis, furuncles, and carbuncles. (Gandhi S, 2012) Rizani's research at Al-Islam Hospital in Bandung found that most pyoderma types were impetigo contagiosa or crustosa(53,5\%). (Rizani FA, Djajakusumah TS, Sakinah RK, 2013)

\section{PyodermaTreatment}

Based on medical record data obtained from the outpatient unit of the Islamic Hospital of Aisyiyah Malang, the treatment of pyoderma is as follows:

Table 5. Pharmacological therapy for patients with pyoderma

\begin{tabular}{lcc}
\hline \multicolumn{1}{c}{ Therapy } & Number of Patients & Percentage (\%) \\
\hline Topical antibiotics & 7 & 15,2 \\
Systemic and topical antibiotics & 24 & 46,5 \\
Systemic antibiotics and NaCL & 15 & 32,6 \\
compress & & \\
\hline
\end{tabular}


Based on the above results, the majority of pyoderma patients received combination therapy, which are systemic and topical antibiotics, as many as 22 cases (43.5\%) received systemic antibiotics and compressed NaCL as many as 15 cases $(32.6 \%)$ and a minority of 7 cases $(15.2 \%)$ received topical antibiotic therapy only.

Therapy on pyoderma in general is by giving antibiotics both topically and orally. Topical antibiotics are given for cases of mild to moderate lesions. Whereas for extensive cases treatment is needed using systemic antibiotics. Compress therapy using normal saline works to eliminate crusting. Crusts need to be removed so that topical medicines can work effectively. Aside from being done on lesions with many crusts, compresses are used for wet lesions. (Craft et al, 2008)

Table 6. Systemic antibiotic therapy

\begin{tabular}{lcc}
\hline \multicolumn{1}{c}{ Systemic antibiotic } & Number of Patients & Percentage (\%) \\
\hline Amoxicillin & 2 & 4,76 \\
Amoxicillin + Clavulamic Acid & 4 & 9,52 \\
Erythromycin & 5 & 11,90 \\
Cefixime & 15 & 35,71 \\
Cefadroxil & 7 & 16,67 \\
Levofloxacine & 5 & 11,90 \\
Clindamycin & 2 & 4,76 \\
Doxycycline & 2 & 4.76 \\
\hline
\end{tabular}

Based on the data, it was found that cefixime antibiotics were most widely used for pyoderma therapy by $35.71 \%$.

Table 7. Topical antibiotic therapy

\begin{tabular}{lcc}
\hline \multicolumn{1}{c}{ Topical antibiotic } & Number of Patients & Percentage $(\%)$ \\
\hline Mupirocin & 12 & 50,00 \\
Na Fucidat & 4 & 16,67 \\
Gentamicin & 8 & 33,33 \\
\hline
\end{tabular}

Based on the data, it is found that mupirocin is the most topical antibiotic given to pyoderma patients. Mupirocin is the first line for topical pyoderma therapy such as impetigo, ecthyma, folliculitis, and furuncle. Mupirocin is also the topical antibiotic of choice for CA-MRSA 
(Community Associated Methicillin Resistant Staphylococcus). (Craft et al, 2008. G Berger T, 2007) The results of this study differ from Prof. Dr. R. D. Kandou Manado General Hospital in the 20132015 period where the topical antibiotics most widely used were fusidic acid (52.63\%), followed by mupirocin (20.18\%), and gentamicin (17.54\%). (Depari LI, Sugiri U, Ilona L, 2016) The same results were also found in previous studies in Dermatovenereology Polyclinic of Prof. Dr. R. D. Kandou Manado General Hospital in 2012. (Caren CP, 2012)

\section{CONCLUSIONS AND RECOMMENDATIONS}

The incidence of pyoderma in Malang Aisyiyah Islamic Hospital throughout 2017 was 46 cases $(11.03 \%)$. The incidence of pyoderma is higher in males as much as $56.52 \%$ and according to age the most is the age group of $0-11$ years $(39 \%)$. The most common level of education is high school which is $34.78 \%$. Most types of pyoderma are impetigo (32.6\%). The most systemic antibiotic therapy used was cefixime at $35.71 \%$ and the topical most frequently used was mupirucin $(42.86 \%)$.

We recommend completeness in filling in the patient's medical record is very needed in order to support a complete, accurate and informative data collection and further data needs predisposing factors which are the habits or patients' daily activities.

\section{REFERENCES}

Caren CP, Herry EJP, Renate TK. ProfilPyodermaPadaAnak Di PoliklinikKulit Dan Kelaminrsup Prof. Dr. R. D. Kandou Manado PeriodeJanuari-Desember 2012

Craft et al, 2008, 'Superficial Cutaneus Infections and Pyodermas in Fitzpatrick's Dermatology in General Medicine', Mc Graw Hill Medicine, New York

Depari LI, Sugiri U, Ilona L,2016,' Relation between Risk Factors of Pyoderma and Pyoderma Incidence', Althea Medical Journal, 3, 3

Djuanda A, Hamzah M, Aisah S, 2011,'Ilmu PenyakitKulitdanKelamin Ed 6', Jakarta, BadanPenerbit FK UI

G Berger T, 2007,'Furunculosis (Boils) and Carbuncles’ In: McPhee SJ, Papadakis MA, Tierney LM (eds),'Current Medical Diagnosis and Treatment 46th ed', New York, McGraw Hill

Gandhi S, Ojha Ak, Ranjan KP et al, 2012,'Clinical and Bacteriological Aspects of Pyoderma ', North American Journal of Medical Sciences, vol $4: 10$

Gandhi S, Ojha AK, Ranjan, Neelima. Clinical and Bacteriological Aspects of Pyoderma. N Am J Med Sci. 2012;4:492-5

John, H. 2013. Bacterial Infections. In: Clinical Dermatology 3rd Ed. USA: Blackwell Science 
LaksmiDewi BAAA, DhanaSaputra IPK, Rusyati LM, Bratiartha MD, Adiguna MS. Profil Pyoderma di PoliklinikKlinikdanKelamin RS Sanglah Denpasar PeriodeJanuari 2006 Desember 2008.

Listya P, Juliyanti, Paramita C, Dwi K. Profil Pyoderma Superfisial di PoliklinikRawatJalan RSUP Sanglah Denpasar Bali PeriodeJanuari-Desember 2015.

Notoatmodjo, S, 2002, 'PendidikandanPerilakuKesehatan', RinekaCipta, Jakarta, pp: 27

Nugraha, Dhimas P, 2017, 'Hubungan Antara Kejadian Pyoderma DenganBerbagaiFaktorRisiko', FakultasKedokterandanIlmuKesehatanUniversitasMuhammadiyah Yogyakarta, Yogyakarta

Priscilia F. Lumataw, PandalekeH, Pieter LS. Profil pyoderma padaanak di PoliklinikKulitdanKelamin RSUP Prof. Dr. R. D. Kandou Manado periodetahun 20132015

Rizani FA, Djajakusumah TS, Sakinah RK. AngkaKejadian, KarakteristikdanPengobatan Impetigo di RS AlIslam Bandung. Prosidingpendidikandokter. 2013;1009-15

WHO, 2005,'Epidemiology and Management of Common Skin Disease in Childrem in Developing Countries', Department of Child and Adolescent Health and Development 